\title{
COL4A5 wt Allele
}

National Cancer Institute

\section{Source}

National Cancer Institute. COL4A5 wt Allele. NCI Thesaurus. Code C71434.

Human COL4A5 wild-type allele is located in the vicinity of Xq22 and is approximately 258 $\mathrm{kb}$ in length. This allele, which encodes collagen alpha-5(IV) chain protein, plays a role in the modulation of the conformation of the extracellular matrix. Mutation or deletion of the gene is associated with Alport syndrome. 